\title{
A New Locality Record for the Yellow-collared Wolfsnake, Lycodon flavicollis Mulherjee and Bhupathy 2007, from Hyderabad, Telangana, India
}

Buddi Laxmi Narayana, Mushkam Sandeep, and Shivani Dogra

Nehru Zoological Park, Hyderabad-500064, Telangana, India (narayana.laxmi8@gmail.com)

$\mathrm{M}$ ukherjee and Bhupathy (2007) described the Yellowcollared Wolfsnake (Lycodon flavicollis) from Mangarai Village on the periphery of the Anaikatti Reserve Forest, Western Ghats, Coimbatore District, Tamil Nadu, southwestern India $\left(11^{\circ} 05^{\prime} \mathrm{N}, 76^{\circ} 47^{\prime} \mathrm{E} ; 600 \mathrm{~m}\right.$ asl). Very little is known about the distribution and natural history of this species. Gupta et al. (2014) recorded it from the Tirupati Hills, Andhra Pradesh, Eastern

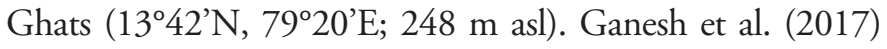
reported a specimen from the Therkumalai Estate, Tirunelveli District, Tamil Nadu $\left(8.93^{\circ} \mathrm{N}, 77.27^{\circ} \mathrm{E} ; 175 \mathrm{~m}\right.$ asl). This locality is in the Coutrallam Hills, which are a part of the Agasthyamalai Range of the southern Western Ghats. Those authors also noted additional photographic records from Magadi $\left(12.95^{\circ} \mathrm{N}\right.$, $77.22^{\circ} \mathrm{E} ; 850 \mathrm{~m}$ asl), Tumkur $\left(13.27^{\circ} \mathrm{N}, 77.18^{\circ} \mathrm{E} ; 850 \mathrm{~m}\right.$ asl), and Hospete $\left(15.25^{\circ} \mathrm{N}, 76.40^{\circ} \mathrm{E} ; 500 \mathrm{~m}\right.$ asl) on the Deccan Plateau of Karnataka. Most recently, Sunkuri (2017) reported a sighting in Sangenenipalli Thanda in the Vepanagandla Mandal, Wanaparthy District, Telangana $\left(16.13^{\circ} \mathrm{N}, 78.16^{\circ} \mathrm{E} ; 441 \mathrm{~m}\right.$ asl).

At 1100 h on 28 July 2017, we rescued a Yellow-collared Wolfsnake on the periphery of the Nehru Zoological Park in the environs of Tadbun Masjid-e-Abubaker Siddiq $\left(17.34^{\circ} \mathrm{N}\right.$, $78.45^{\circ} \mathrm{E} ; 519 \mathrm{~m}$ asl), Hyderabad, Telangana, India (Fig. 1). We identified the snake as an adult male by the presence of a wide yellow collar that extends to the back of the head. Total length was $46 \mathrm{~cm}$, SVL $39 \mathrm{~cm}$, and head length $2 \mathrm{~cm}$. We deposited digital-image vouchers at the Lee Kong Chian Museum of Natural History, National University of Singapore (ZRC [IMG] 2.326; Fig. 2). After examination, we released the snake into natural habitat. On 15 August 2017, another snake was found dead at the same locality (total length 27.2 cm; SVL $22.5 \mathrm{~cm}$; head length $1.2 \mathrm{~cm}$; Fig. 3). These records extend the known range of the species $138 \mathrm{~km}$ to the north.

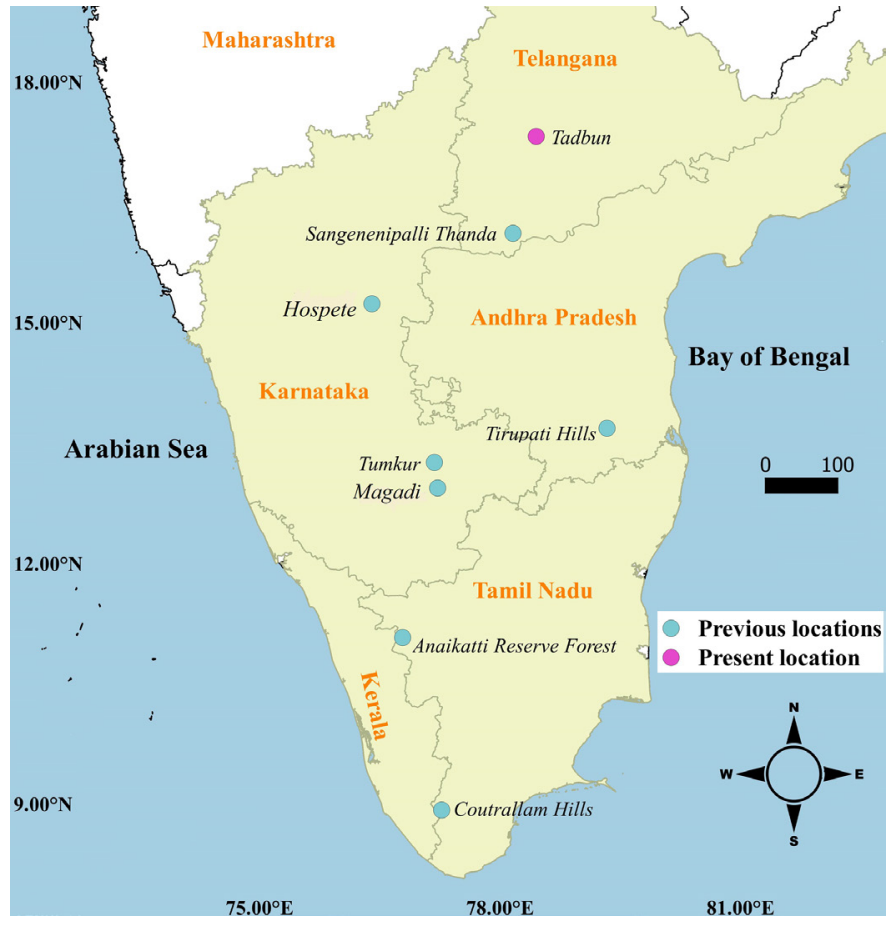

Fig. 1. Map of southern peninsular India showing currently known locality records for the Yellow-collared Wolfsnake (Lycodon flavicollis).

\section{Acknowledgements}

We thank Zoo Director Mr. S. Kookretty, CCF, Rangareddy Circle, and zoo staff members of the Telangana State Forest Department for their continuous support and encouragement. We also thank reptile house animal keepers, Mr. A. Prabhakar, Mr. M. Subhash, Mr. A. Sachin, and A. Anil for rescuing the snake. 


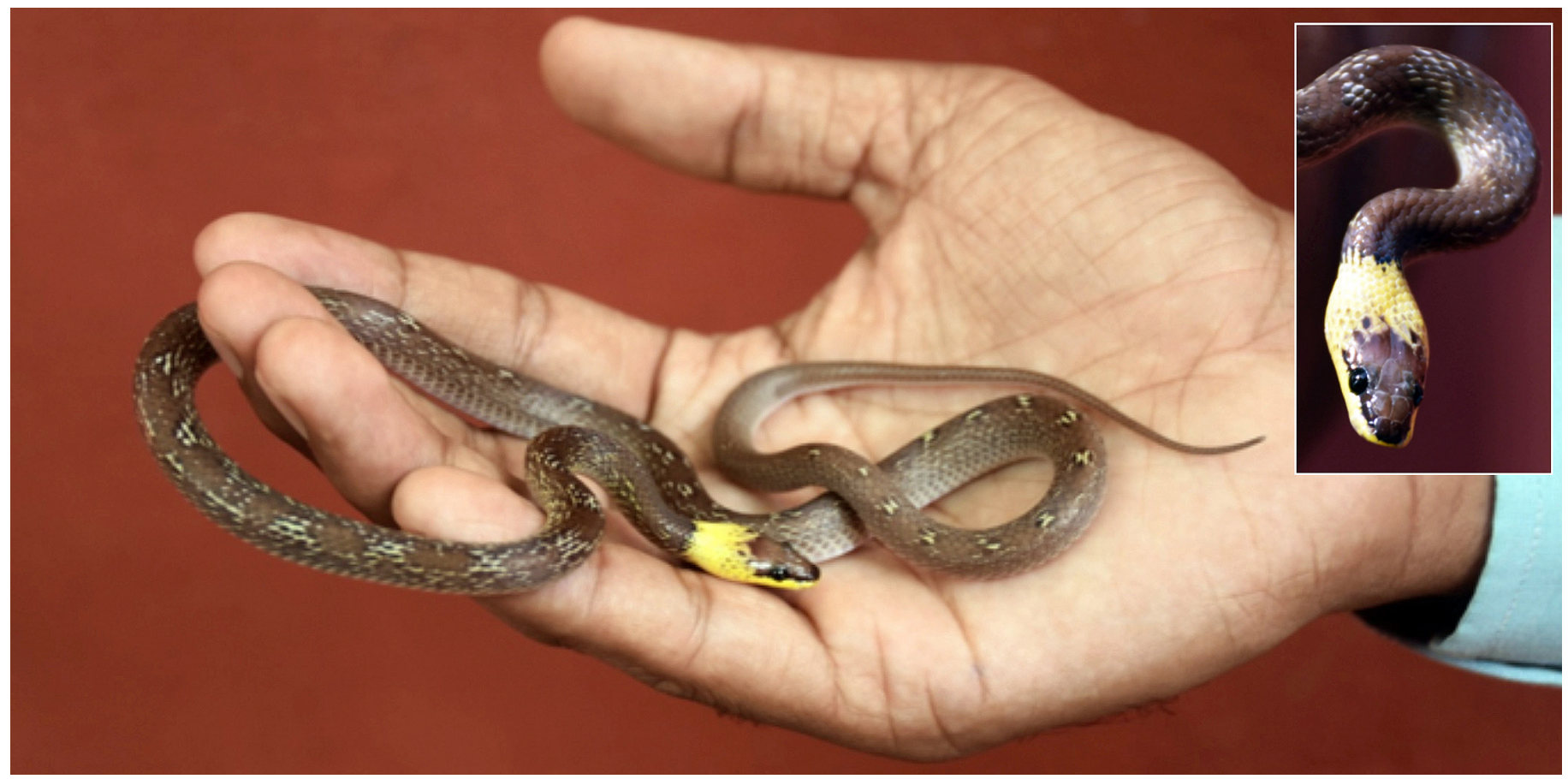

Fig. 2. A rescued Yellow-collared Wolfsnake (Lycodon flavicollis) in the Tadbun Area, Hyderabad, Telangana, India. Note the wide yellow collar that extends to the back of the head. Photographs by Mushkam Sandeep.
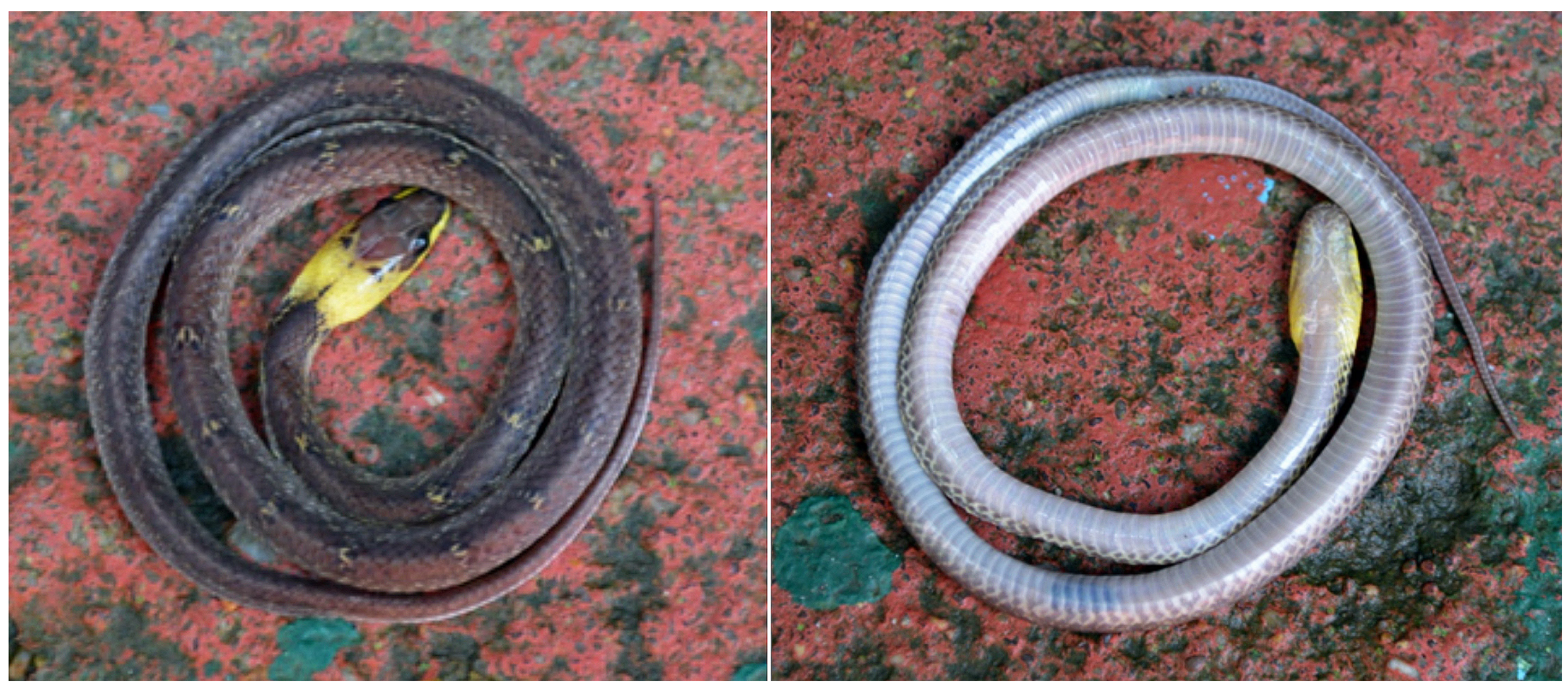

Fig. 3. Dorsum (left) and venter of a Yellow-collared Wolfsnake (Lycodon flavicollis) from the same locality as that in Fig. 2. Photographs by Buddi Laxmi Narayana.

\section{Literature Cited}

Ganesh, S.R., M. Rameshwaran, and N.A. Joseph. 2017. Nachweis einer HalsbandWolfsnatter, Lycodon flavicollis Mukherjee \& Bhupathy, 2007, aus den Coutrallam Hills, südliche Western Ghats, Indische Halbinsel. Sauria 39(1): $58-61$.

Guptha, B.M., T. Thulasaiah, and S.N.V Prasad. 2014. New locality record of Yellow Collared Wolf Snake Lycodon flavicollis Mukherjee and Bhupathy,
2007 from Seshachalam Biosphere Reserve, Eastern Ghats, Andhra Pradesh, India. Journal of Research in Biology 4: 1328-1331.

Mukherjee, D. and S. Bhupathy. 2007. A new species of wolf snake (Serpentes: Colubridae: Lycodon) from Anaikatti Hills, Western Ghats, Tamil Nadu, India. Russian Journal of Herpetology 14: 21-26.

Sunkuri, N. 2017. Rare serpent spotted. The Hans India, 18 April 2017 (http:// www.thehansindia.com/posts/index/Telangana/2017-04-18/Rare-serpentspotted/294202). 